\title{
Quickening nature's pulse: atomic agriculture at the International Atomic Energy Agency
}

\author{
Jacob Darwin Hamblin (*)

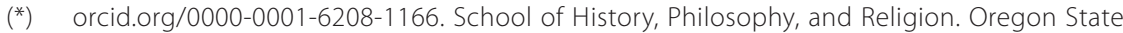 \\ University. jacob.hamblin@oregonstate.edu
}

Dynamis

[0211-9536] 2015; 35 (2): 389-408

http://dx.doi.org/10.4321/S0211-95362015000200006
Fecha de recepción: 14 de julio de 2014

Fecha de aceptación: 23 de abril de 2015

SUMMARY: 1.-Introduction. 2.-Favors from nature. 3.-Empire-building at the International Atomic Energy Agency. 4.-Claiming victories. 5.-Conclusion.

ABSTRACT: Mutation breeders in the 1960s seemed poised to use atomic energy to speed up mutation rates in plants in order to develop new crop varieties, for the benefit of all people. Although skepticism had slowed this work in the United States, the International Atomic Energy Agency (IAEA) nurtured the scientific field, its community of experts, and an imagined version of the future that put humans in control of their destiny. The IAEA acted as a center of dissemination and support for experts and ideas even when they had fallen from favor elsewhere. Through the lens of the IAEA, plant breeding bore the appearance of a socially progressive, ultra-modern science destined to alleviate population pressures. Administrators at the IAEA also were desperate for success stories, hoping to highlight mutation plant breeding as a potential solution to the world's ills. The community of mutation plant breeders gained a lifeline from the consistent clarion call from the Vienna-based agency to use atomic energy to understand the natural world and quicken its pulse with radioisotopes.

KEY WORDS: International Atomic Energy Agency, Food and Agriculture Organization, mutation plant breeding, Atoms for Peace, radiation botany.

\section{Introduction}

The story of the Green Revolution, with its hybrid strains of rice and wheat fending off the population crisis in the 1970s, was slightly tarnished by the suicide of a plant breeder in India. Vinod Shah had been working in an institution led by his country's most celebrated scientist, Monkombu Sambasivan Swaminathan, dubbed the «guru of the Green Revolution». Swaminathan had been instrumental in bringing to India the «miracle» 
wheat developed in Mexico that grew so well on the farmlands of India and Pakistan, and had used radioactive sources to speed up the natural mutation rates of plants. He claimed to have used radiation to increase the protein content of wheat. The work suggested that radioisotopes held the key to manipulating natural processes for the benefit of all, and it strengthened the connections being drawn, especially by academics and politicians in industrialized countries, between scientific research and the development of the Global South ${ }^{1}$. When Shah killed himself in 1972, he left a note that implied that the apparent protein result had taken on a life of its own, with such obvious political importance that it had become virtually impossible in India to question the optimistic claims emerging from the scientific work. Addressing Swaminathan, he wrote that «a lot of unscientific data are collected and passed on to you to fit your line of thinking». The claim of increased protein content was later demonstrated to be exaggerated at best, completely spurious at worst ${ }^{2}$.

In the 1960s, mutation breeders such as Swaminathan seemed poised to use atomic energy to speed up mutation rates in plants in order to develop new crop varieties, for the benefit of all people. The US had once been the center of such work. But in the 1960s, skepticism had slowed this work in the US and tempered enthusiasm. Yet Swaminathan and other scientists like him enjoyed the backing of a community of experts at the International Atomic Energy Agency (IAEA), who encouraged them to build up mutation plant breeding in their countries and to connect their research to problems facing the developing world. Despite considerable opposition, and lacking evidence that atomic agriculture was worth the investment, the IAEA nurtured a scientific field, a community of experts, and an imagined version of the future that put humans in control of their destiny, powered by the atom.

1. Scholars in recent decades have connected these notions of development to ideological competition, cultural chauvinism, and neocolonialism. Escobar, Arturo. Encountering development: the making and unmaking of the Third World. Princeton: Princeton University Press; 2011; Moon, Suzanne. Takeoff or self-sufficiency? Ideologies of development in Indonesia, 1957-1961. Technology and Culture. 1998; 39(2): 187-212; Cullather, Nick. The hungry world: America's cold war battle against poverty in Asia. Cambridge: Harvard University Press; 2010; Perkins, John H. Geopolitics and the green revolution: wheat, genes and the cold war. New York: Oxford University Press; 1997.

2. Dr. Vinod Shah's protest by suicide. Nature. 19 May 1972; 237:130. See also Hanlon, Joseph. Top food scientist published false data. New Scientist. 7 Nov 1974: 436-437. 
The present essay highlights the role of the IAEA to act as a center of dissemination and support for experts and ideas even when they had fallen from favor elsewhere. The IAEA periodically injected enthusiasm and support for various atomic-related fields in the latter half of the twentieth century, especially mutation plant breeding. Marginalized by scientific communities in their home countries and often unable to acquire sustained funding, mutation plant breeders used the IAEA as a lifeline, to bolster the credibility of their research programs and to gain high-profile attention for their methods. Despite widespread views among scientists of its dubious value, mutation plant breeding bore the appearance - through the lens of the IAEA - of a socially progressive, ultra-modern science destined to alleviate population pressures. Administrators at the IAEA took this support so far that they were desperate for success stories, hoping to highlight mutation plant breeding as a potential solution to the world's ills. The science of mutation plant breeding, rarely a mainstream or even highly respected field in the US and Europe, gained strength from the consistent clarion call from the Vienna-based agency to use atomic energy to understand the natural world and quicken its pulse with radioisotopes.

\section{Favors from nature}

Mutation plant breeding's most compelling argument was that it made humans shapers of their own destinies. The notion was similar to that espoused by the Russian Trofim Lysenko, who insisted that humans did not have to wait for favors from nature. Real science was progressive, in which human hands shaped the course of natural evolution. Lysenko attacked Darwinian evolution and Mendelian genetics, with their emphasis on unpredictable mutations. Mutation plant breeders took a different approach - they accepted randomness of mutations but empowered themselves by hastening the process with intensive radiation. In the 1950s, the American scientist Lloyd Berkner, president of Associated Universities, captured this ethos when he marveled at mutation crop breeding: «It is as though, for evolutionary purposes, we had collapsed a thousand years into one» ${ }^{3}$.

3. Manchester, Harland. The new age of atomic crops. Popular Mechanics. Oct 1958: 106-110, 282-288 (108). 
Design by humans, and the ability to use science as a tool for social and economic progress, lent special importance to mutation breeding. Before the American Hermann J. Muller had shown in 1927 that X-Rays could induce mutations in fruit flies, geneticists often spoke of genes as untouchable, not subject to influence from the environment. Radiation changed that conversation because it seemed to put the power of design back into the hands of scientists ${ }^{4}$. Muller's 1927 work, published prominently in Science, became the foundational text for modern mutation plant breeding ${ }^{5}$. "If mutations can be produced artificially and at will in plants and animals, the work of the animal and plant breeder will be greatly accelerated» wrote The Scientific Monthly in 1928. «We shall no longer need an empirical genius... but shall obtain our results by quantitative laboratory methods» 6 .

Optimistic statements about design seemed to be backed up by research. When plant breeders subjected crop plants at various stages of development to X-Ray and radium treatment, they found entirely new mutations, sparking a fire of interest among amateur gardeners and academic scientists alike ${ }^{7}$. At the University of California, T. H. Goodspeed claimed to have gotten results similar to Muller's from the irradiation from tobacco plants. University of Missouri botanist Lewis J. Stadler presented evidence in the late 1920s of conspicuous seedling characters for corn and barley. After a meeting of the American Association for the Advancement of Science - at which Muller received an award of $\$ 1,000$ for having presented the most notable paper- one writer reflected:

«It is agreed on all sides at the gatherings of scientific men that the past year has been one of revolution in the study of heredity among living things, comparable with 1859, when Darwin published the Origin of Species, and 1900 , the year of the rediscovery of Mendel's law» ${ }^{8}$.

4. Chemical substances, especially colchicine, also induced mutations, and this excited the interests of plant breeders as well. Curry, Helen Anne. Making marigolds: colchicine, mutation breeding, and ornamental horticulture, 1937-1950. In: Campos, Luis; von Schwerin, Alexander, eds. Making mutations: objects, practices, contexts. Berlin: Max-Planck-Institut für Wissenschaftsgeschichte; 2010, p. 259-284.

5. Muller, H. J. Artificial transmutation of the gene. Science. 1927; 66 (1699): 84-87.

6. Advances in biophysics. The Scientific Monthly. 1928; 26 (2): 189-190.

7. Curry, Helen Anne. From garden biotech to garage biotech: amateur experimental biology in historical perspective. The British Journal for the History of Science. 2014; 47 (3): 539-565.

8. Stadler, L. J. Mutations in barley induced by X-rays and radium. Science. 1928; 68 (1756): 186-187. 
But would this really live up to the enthusiasm expressed by Muller and so many others?

One of those who cared deeply about these questions was Swedish botanist and geneticist Åke Gustafsson, later dubbed the «father of mutation breeding» ${ }^{9}$. In the 1930s, spurred on by Muller's excitement, Gustafsson did his doctoral work on artificial mutations in barley. Although Stadler had demonstrated that it was possible to induce mutations, he had concluded that the proportion of deleterious mutations made radiation seem impractical. Gustafsson, on the other hand, reasoned that a huge amount of wasted crop material would be worth the gain of a good mutant. His work spoke directly to the interests of the Swedish government in maximizing yields on limited amounts of arable land, especially when Sweden's weak-stemmed barley crops began to be replaced by stiff-stemmed plants developed by Gustafsson.

In public discourse, the work of Muller and Gustafsson took on the tone of social progress through directed evolution ${ }^{10}$. The magazine Popular Mechanics, many years later, reported that Gustafsson «in a few years found that they could step up nature's mutation rate as much as a thousandfold». His name was attached to radiation-induced successes, such as a new mustard plants that yielded ten percent more vegetable oil per acre than existing varieties, and the «Ray Pea» (named for the X-Ray), with a pod some thirty percent larger than its parents. The language of journalists put scientists in control of processes, with red apples «forced out of trees which bore yellow fruit, and russet pears from trees that bore smooth ones» ${ }^{11}$. Radiation was a new tool - for penetrating into the genetic material and transforming species.

With cooperation from geneticists, the atomic bomb itself could be cast as a progressive improvement tool. American botanists brought seeds of barley, wheat, and oats with them to the South Pacific for a series of atomic bomb tests in 1946. The seeds exposed to one particular explosion -codenamed ABLE- were then grown in Arizona. The mutants observed were collected

9. van Harten, A. M. Mutation breeding: theory and practical applications. Cambridge: Cambridge University Press; 1998, p. 55.

10. Leningrad Academy of Agricultural Sciences of the U.S.S.R. The situation in biological science. Moscow: Foreign Languages Publishing House; 1949, p. 34; Gustafsson, Åke. Marxist genetics at the Stockholm Botanical Congress. Journal of Heredity. 1951; 42 (2): 55-59 (55).

11. Manchester, Harland. The new age of atomic crops. Popular Mechanics. 1958; Oct: 106-110, 282-288 (288). 
and planted at various field stations. State College of Washington botanist Luther Smith discovered that at least one of these mutants was dominant. It was a golden-colored durum wheat, and the dominant gene was passed on according to Mendelian laws. Here was a clear case of atomic radiation introducing an important and viable gene (not just a damaged chromosome) into nature ${ }^{12}$.

Scientists at the dawn of the atomic age used such findings to argue that mutation plant breeding might provide the key to guided evolutionary change. A member of Gustafsson's group in Sweden, Diter von Wettstein, claimed that «by radiation we can get almost anything out of a plant we really want». He said that most food plants were «old fashioned» needing reconstruction. «We now have an instrument with which we can rebuild all the food plants in the world $»^{13}$. It was powerful imagery - rebuilding nature. It took hold in press coverage of atomic energy applications in agriculture, implying that the atom would help design, shape, and rebuild nature.

In reality, although this work arguably made contributions to the development of new beneficial mutations, its main justification was in studying the effects of radiation exposure from nuclear weapons and fallout. Even when substantially supported, little of the work on radiation-induced mutation was specifically oriented toward developing new varieties. The most extensive research program for plant irradiation was at Brookhaven National Laboratory, in New York, where Arnold H. Sparrow had begun a large-scale program on what was known as «radiosensitivity» research. Brookhaven's first gamma field came into use in 1948, with a relatively small source of Cobalt-60, producing just 16 curies of radiation. When he and others ramped up this work in the 1950s, Sparrow noted that there was almost no information available about the effects of radioactive fallout from nuclear tests, and certainly none about the expected radiation effects of a nuclear war on the natural environment. What information existed was not plant-specific. So, Sparrow set out to study the effects of radiation exposure to many different kinds of plants, at varying degrees of radiation exposure, using Cobalt sources producing thousands of curies. These studies were designed to understand how what load of radiation could be absorbed by

12. Smith, Luther. A rare dominant chlorophyll mutant in durum wheat. Journal of Heredity. 1952; 43 (3): 125-128.

13. Manchester, n. 11, p. 288, 284. 
trees, crops, and foliage in the event of nuclear catastrophe, or of long-term exposure to continuous doses of radiation ${ }^{14}$.

Despite the press coverage about this radiosensitivity research, mutation plant breeding per se did not enjoy widespread financial support in the US or Europe, either from atomic energy establishments or among plant breeders. It did not substantially expand beyond the framework of nuclear weapons effects. The gamma field at Brookhaven yielded only marginally interesting results. Some peach mutants were ripening faster than usual, and they managed to get clingstone peaches to grow on freestone peach trees. Since baby food producers preferred clingstones, this was advertised as good news ${ }^{15}$. However, most plant breeders felt that there were already plenty of varieties existing in nature, and that the most promising paths lay in hybridization of existing traits, not mutating new ones. Even at Brookhaven, the new traits were scientific curiosities, side stories to the main narrative of exposure to nuclear radiation. The studies were not designed to feed people in the developing world. Yet the drama of the story was nearly irresistible: gamma fields and other centers for radiationinduced mutation were designed to wrest, rather than await, favors from nature. For the research to continue, mutation plant breeding would need institutional support that was just as enthusiastic, and willing to make optimistic projections, as were writers for popular magazines. They would get precisely that from the IAEA.

\section{Empire-building at the International Atomic Energy Agency}

The widespread diplomatic support enjoyed by the IAEA in the mid1950s, especially from the US and United Kingdom, made it an attractive place to pursue atomic energy applications in agriculture ${ }^{16}$. The agency itself was a direct result of 1953 Eisenhower's Atoms for Peace speech and subsequent initiative to create a peaceful atomic energy agency ${ }^{17}$. At the

14. Sparrow, Arnold H. Research uses of the gamma field and related radiation facilities at Brookhaven National Laboratory. Radiation Botany. 1966; 6 (5): 377-405.

15. Manchester, n. 11, p. 108.

16. See Karin Zachmann's work, especially in present issue of Dynamis.

17. For an extensive account of the enthusiasm for radioisotopes in the postwar era, Creager, Angela N. H. Life atomic: a history of radioisotopes in science and medicine. Chicago: University of Chicago Press; 2013. 
first International Conference on the Peaceful Uses of Atomic Energy, held in Geneva in 1954, several agricultural experiments were on display. One was the "White Sim» carnation, in which the typical red streak apparently had been wiped clean, giving the appearance of a pure white flower. A Brookhaven creation, the White Sim stood out among many other examples that promised a future of pretty flowers, early harvests, abundant timber, and foods of endless variety ${ }^{18}$.

The efforts of the IAEA to prop up mutation breeding flew in the face of considerable skepticism among its advisors, who saw it as a boutique field of fringe interest to plant breeders. Agricultural specialists at FAO (prior to 1964) and in most countries belittled it as unproven and wasteful compared to conventional breeding methods ${ }^{19}$. Perry R. Stout, a professor of soil science at the University of California, was one of several who told the agency to focus on fertilizer studies, not plant breeding. With radioisotopes, the pathways of fertilizer could be monitored in soil, with an eye toward making the flow of nutrients as efficient as possible. Like others, Stout was wary of the IAEA's commitment to mutation breeding in the developing world ${ }^{20}$.

In the first few years of the IAEA, fertilizer work did rank high on the list of priorities, along with some attempts at disinfesting grain and sterilizing insects to control diseases (the sterile male technique). Scientists doubted whether mutation breeding could live up to the hype. «Except in very favorable cases», British radiobiologist R. Scott Russell pointed out, «the labour involved in selecting the valuable mutations from the much larger number of useless ones is a formidable task» ${ }^{21}$. Similarly, Cambridge plant breeder G. D. H. Bell wrote to colleagues at the IAEA:

«Personally I feel that the application of any method for the artificial induction of mutations is more in the nature of being an interesting scientific

\footnotetext{
18. Manchester, n. 11.

19. Hamblin, Jacob Darwin. Let there be light... and bread: the United Nations, the developing world, and atomic energy's green revolution. History and Technology. 2009; 25: 25-48.

20. Perry R. Stout (University of California) to Harold H. Smith (IAEA), 31 Dec 1958, IAEA Archives, SC/822 PT I.

21. R. Scott Russell (Agricultural Research Council, Radiobiological Laboratory, Wantage) to K. C. Tsien (Department of Research and Isotopes, IAEA), 12 Jan 1960, IAEA Archives, SC/735-1.
} 
experiment rather than directly useful in the economic sense of the term, i.e. the production of improved varieties» 22 .

Bell put greater confidence in traditional methods, namely selecting the best of the existing varieties and/or hybridizing them. Bell tried to be positive about the IAEA's work but wrote adamantly that there was no good evidence to suggest that mutation plant breeding made economic sense. Similarly, scientists at the US's Brookhaven National Laboratory were dismissive about the usefulness of gamma fields for economically important agricultural research. Harold $\mathrm{H}$. Smith wrote, «With regard to general agricultural usefulness of gamma fields in underdeveloped countries, I have grave doubts». He argued that this kind of work was best left to countries with high levels of technical competence and agricultural development ${ }^{23}$.

With all this advice against promoting mutation breeding in developing countries, IAEA administrators faced a dilemma. What if scientists were unwilling to listen to advice, and wished to pursue atomic solutions despite arguments against? In other words, what if they were building their own empires back home? The IAEA had solicited these opinions because a Japanese scientist, Kiyoshi Kawara, was trying to create a governmentsponsored National Gamma Field, to be used for agricultural research under the auspices of Japan's Ministry of Agriculture and Forestry. IAEA Deputy Director-General Henry Seligman told Kawara that most experts believed gamma fields were unlikely to lead to economically important results. But this did not deter Kawara, who already was committed to the national program. He acknowledged that gamma fields were unlikely to solve plant breeding problems; he agreed that other sources of radiation (like X-Rays) often did a better job of inducing mutations; and he conceded that gamma field programs were expensive to maintain. But with perennial plants, Kawara wrote to Seligman, gamma fields might prove useful for breeding. By the time he wrote, his title had become «Director, the National Gamma Field» ${ }^{24}$.

Scientists at the IAEA carefully observed Kawara's strategy and soon learned from it. He had used the prestige of external support to justify

22. G. D. H. Bell (Cambridge Univesity) to K. C. Tsien (Department of Research and Isotopes, IAEA), 12 Jan 1960, IAEA Archives, SC/735-1.

23. Harold H. Smith (Brookhaven National Laboratory, USA) to K. C. Tsien (Department of Research and Isotopes, IAEA), 27 Jan 1960, IAEA Archives, SC/735-1.

24. Kiyoshi Kawara (Director, the National Gamma Field, Japan) to Henry Seligman (Deputy Director General, Department of Research and Isotopes, IAEA), 13 May 1960, IAEA Archives, SC/735-1. 
soliciting support from his own government. The US Atomic Energy Commission in 1957 had offered to provide Japan, free of cost, with a 200-curie cobalt source to make a gamma field. Having received this encouragement from the US, Japan's Ministry of Agriculture and Forestry convened a panel to decide the future of the gamma field, and it used the prodding from the US to justify a different design for the gamma field, to acquire a much larger source of gamma radiation (17 pieces of Co-60 producing more than 2,000 curies), and to generate government funding for it. In the end Japan even declined the «magnanimous offer» from the US. By the time it opened in 1962, the facility had cost 230 million Yen $(\$ 640,000)$. Kawara announced that the Japanese were in the process of exposing just about every conceivable plant to gamma radiation, and that there already were promising new mutations in roses, carnations, and other flowers ${ }^{25}$.

Kawara's experience highlighted a new opportunity to use the prestige of the IAEA to lend credibility to scientists' programs and help them build scientific communities at home. This is precisely what began to happen when Icelandic botanist Björn Sigurbjörnsson took a post at the IAEA. Sigurbjörnsson, a former student of Åke Gustafsson, wanted to develop a coordinated international program of mutation plant breeding, to focus on improving rice. He set his sights on Asia, and the first direction he turned was toward Japan. By 1964 Kawara's gamma field had been operational for three years, and Sigurbjörnsson hoped that the Japanese scientists there would be ideal collaborators in establishing an Asian-focused research program in mutation plant breeding. But he also hoped to reach out to scientists at the International Rice Research Institute in Philippines, as well as researchers in Thailand and India. His goal was to build, through modest grants, a system of researchers on plant mutation connected to the IAEA, and to create a kind of mutagen pool to which all participants might have access ${ }^{26}$.

With all this interest, Sigurbjörnsson was struck with a brilliant idea to extend the IAEA's role: the creation of an «International Mutation Group» that would include not only developing countries but anyone at all working on methods to produce and use induced mutations in plant breeding. It

25. Kawara, Kiyoshi. Introduction of a gamma field in Japan. Radiation Botany. 1963; 3: 175-177.

26. Björn Sigurbjörnsson to Sumumu Nishigaki, 8 May 1964, IAEA Archives, SC/822 (5) PT I. See also Björn Sigurbjörnsson to Y. Yamasaki (National Institute of Agricultural Sciences, Japan), 11 May 1964, IAEA Archives, SC/822 (5) PT I. 
would be organized by the IAEA, with annual conferences and a printed information circular ${ }^{27}$. Rather than see the developing world's enthusiasm as a problem - one based on unrealistic expectations - he saw it as an opportunity to revitalize the downtrodden programs in richer countries.

What made the plan brilliant was Sigurbjörnsson's contract strategy, which exploited industrialized countries' existing commitments to IAEA programs. He offered a special kind of contract from the IAEA, dubbed the «cost-free» contract, targeting scientists in industrialized countries. In theory these would be contracts in name only, involving no expenditure on the part of the IAEA. Although some scientists wondered why on earth they might want such a thing, others caught on right away. A «cost-free» contract would give the appearance of support from the IAEA, lending prestige and relevance to scientists' work back home, opening a door for government funding, shoring up home university support, and possibly leading to other patrons taking an interest. Sigurbjörnsson was offering the indirect benefits of an IAEA support without actually paying anything.

The strategy leveraged the prestige of the IAEA to lend legitimacy to mutation plant breeding among scientists threatened with diminished funding. In a letter to an American colleague, Sigurbjörnsson was quite explicit about the reason behind the «cost-free» contracts, referring to the German breeder Horst Gaul. «This thing started as a way to help Horst get money to continue his research after the AEC called it quits» he wrote. «The idea was that the Agency could give him moral support by awarding him a "cost-free" contract and by dropping the right hint in the right places». Sigurbjörnsson then decided to think of it as a way to bolster support for an international group of researchers that had been sidelined in their home countries $^{28}$. In another letter, Sigurbjörnsson described how he had used his office to support mutation breeding for the Germans Horst Gaul and Werner Gottschalk:

«The "developed" (rich?) Member States of the Agency have officially declared that they are willing to do research as part of the Agency's programmes

27. The «cost-free» concept is in Björn Sigurbjörnsson to Arne Hagberg, (EUCARPIA, Sweden), 20 Oct 1974, IAEA Archives, SC/822 (5) PT I.

28. Björn Sigurbjörnsson to R. S. Caldecott (University of Minnesota), 3 Dec 1964, IAEA Archives, SC/822 (5) PT I. 
free of charge... As it turns out in practice such contracts can directly increase the research budget of the institute in question» ${ }^{29}$.

Because the IAEA was financed by the rich countries, its blessing carried with it the illusion of scientific support by the most advanced countries.

That illusory support also meant that the IAEA could promote mutation plant breeding in the developing world, on the premise that it had the strong backing of industrialized countries. The prestige of modern-sounding atomic energy, and such an apparently-thriving research community among rich countries, meant that there was no shortage of governments from the so-called developing world wanting advice for a program in mutation plant breeding. Sigurbjörnsson's office received letters from around the world from officials keen on accelerating the process of modernization by applying the latest scientific techniques. Newly-communist Cuba, for example, told the IAEA that it wanted to start gamma field experiments soon under its Instituto Nacional de Reforma Agraria. This was a new organization created by Cuba's 1959 Agrarian Reform Law, which confiscated and redistributed large land holdings throughout Cuba. By 1964 the institute was looking to start improving crop yields with radiation ${ }^{30}$. To the Cubans and to others, Sigurbjörnsson repeated that gamma fields were only likely to yield worthwhile results in countries with highly developed plant breeding expertise ${ }^{31}$. But this did not stop requests for assistance.

Although its hollow grant system served the purpose of propping up a dying research agenda, IAEA administrators were very sensitive to the lack of a genuine success, and they craved high-profile success stories from the developing world. One of their strategies was to try to tap into the energies of the existing hybrid researchers in the Philippines, home of the International Rice Research Institute (IRRI), an organization financed by the Ford and Rockefeller Foundations. Takeshi Kawai and M. S. Swaminathan (mutation breeders in Japan and India, both members of Sigurbjörnsson's group) visited IRRI and tried to drum up enthusiasm for the IAEA's work. Unfortunately, by the time they visited in 1966, IRRI already was overwhelmed with the

29. Björn Sigurbjörnsson to R. N. H. Whitehouse (Plant Breeding Institute, Cambridge, UK), 10 Dec 1964, IAEA Archives, SC/822 (5) PT I.

30. Ing. C. L. Ugás Rosso (IRRA, Cuba) to Henry Seligman, 21 May 1964, IAEA Archives, SC/735-1.

31. An example of the IAEA's caveats to interested parties is Björn Sigurbjörnsson to Ing. C. L. Ugás Rosso (IRRA, Cuba), 24 Jun 1964, IAEA Archives, SC/735-1. 
gene pool provided by nature. As Kawai told Sigurbjörnsson, Jennings and his colleagues had «a huge gene source in their excellent collection of rice varieties and triple crops in a year enable them to breed new 'spectacular' varieties in three or four years» ${ }^{32}$. They saw little reason to divert energy and resources to mutation breeding.

IRRI scientists were as dismissive as most of the other skeptics about radiation as an important tool to achieve their goals. The American Peter Jennings, the lead plant breeder there, had since 1961 been trying to amass a significant collection of germplasm. He and colleague T. T. Chang had sent requests to institutes and experimental stations in dozens of countries, trying to build upon their meager collection of about three hundred varieties. He later recalled the surprising result: «I guess within two or three years we had, well I suppose several thousand accessions». For IRRI, it was an exciting time for breeding rice - figuring out how to make hybrids efficiently, how to break dormancy in grains, and trying to imagine what an ideal high-yielding plant might look like. They already had identified one particular hybrid that resembled the ideal - a high-yielding variety called IR $8^{33}$. That high-yielding variety, IR8, became a huge success story in Asia. It became the cornerstone, for rice, of the Green Revolution in Asia ${ }^{34}$. There was little room, and no need, for mutation breeding in their work. Further, mutation breeders seemed to have missed the proverbial boat, because the new miracle grains were unconnected to radiation work. That would not prevent them from trying to claim a few successes.

\section{Claiming victories}

Despite not playing a part in developing the so-called miracle grains making news in the 1960s, mutation breeders at the IAEA were determined to claim a role in the Green Revolution. They did so by making audacious claims about the quality of radiation-induced varieties of grain. One of these supposed success stories was in durum wheat, or «hard» wheat, typically used for

\footnotetext{
32. T. Kawai to Björn Sigurbjörnsson, 16 Mar 1966, IAEA Archives, SC/822 (5) PT II.

33. Interview with Peter Jennings, conducted by Gene Hettel, 20 Jul 2007. Available at http:// archive.irri.org/publications/today/Jennings.asp [accessed 3 Nov, 2010].

34. International Rice Research Institute, press release, «Institute Names a New Rice Variety», 28 Nov 1966, IAEA Archives, SC/894-1.
} 
pasta, couscous, and the bulgur often found in Middle East dishes such as tabbouleh. The Italian standard was an old variety called Cappelli, which was high-yielding by the standards of times past. However, in recent years Italian farmers had made intensive use of chemical fertilizer, introducing new kinds of bread wheat that responded well to it. When such fertilizer was applied to the Cappelli wheat, it grew taller and often «lodged», bending over or breaking. The fertilizer actually decreased yields. Attempts to cross Cappelli with lodging-resistant varieties failed to produce the same tasty Italian pasta. However, scientists at the nuclear research center in Casaccia treated Cappelli seeds with neutron bombardment. In doing so, they produced many mutations and could select those with shorter and/or stronger stems, while still holding onto many of the other desired qualities of Cappelli. In the IAEA's telling of events, the two most successful mutants from this, Castelfusano and Castelporziano, were shorter and stronger than Cappelli, and - because of the fertilizer- higher-yielding than Cappelli. Sigurbjörnsson wrote, «their grain quality remains nearly the same as that of Cappelli for one of the mutants; the other has a quality that is lower but still acceptable» ${ }^{35}$.

This was the IAEA's version of a success story.

To explore these supposed improvements, in the 1960s, FAO and IAEA sponsored the planting of several irradiated varieties of the durum wheat. Although it seemed promising to the IAEA, it did not always fit the interests of local populations. In Egypt, for example, plant breeders were looking for ways to improve bread wheat, not durum wheat. In Iran, where wheat and barley were the most important crops, scientists had failed to find ways to increase yields without planting varieties requiring substantial amounts of fertilizer and water.

In other places, such as Israel and Turkey, the durum wheat mutants were faring well compared to local varieties. Sigurbjörnsson encouraged scientists in these countries to apply to the IAEA for aid. If any of these varieties could be shown as viable, it would be a great boon to the IAEA, and bolster the credibility of the science. So he helped them to write their grant applications, even giving them template wording along the lines of «The International Trials of Durum Wheat Mutants run by the Agency and 
the FAO [...] have shown the value of induced mutations for improvement of yield and lodging resistance in wheat» ${ }^{36}$.

In their efforts to persuade developing countries that there were promising mutants to use, IAEA scientists met fierce resistance from within their own ranks. Botanist Ronald Silow, on staff at FAO, had begun to issue strong statements against the entire program on induced mutations. The agency's official report on the durum wheat trials stated that the mutants tested in nine countries in North Africa and the Middle East had out-yielded all local and other common varieties. Silow wrote to Sigurbjörnsson:

«That statement is patently contrary to the scientific evidence available [...] from those trials and should be deleted. From that statement member governments are being led to the false conclusion that radiation-induced mutation has already provided varieties of wheat better than any other varieties available to farmers in that wide region» ${ }^{37}$.

Silow argued for more objective statements from IAEA and FAO, since anything they might say on the subject would likely influence many governments' policies. Silow hoped the 1964 merger of two FAO and IAEA groups (both on atomic energy applications in agriculture) would help tone down these claims, but he was wrong. In fact, Silow himself faced hostility from IAEA, his career plummeted, and his criticisms were quashed ${ }^{38}$.

A few key scientists in developing countries were building impressive research programs and the IAEA gave them as much political support as possible. In India, Swaminathan was swiftly gaining notoriety for his and others' work increasing the protein content of wheat by raising lysine content. He had taken some of the new wheat varieties developed at the International Maize and Wheat Improvement Center, in Mexico, and had begun to irradiate them. One of the results was a new variant of Sonora-64 wheat (now renamed Sharbati Sonora) that was amber-colored. This he deemed a success because it looked more like the wheat that Indians normally consumed, and thus was likely to attract more consumers than the wheat imported from the Mexico breeding center. Moreover, it appeared to be high in protein and lysine, an essential amino acid found in higher levels

\footnotetext{
36. Björn Sigurbjörnsson to Henry Seligman, 2 May 1967, IAEA Archives, SC/822 (5) PT IV.

37. R. A. Silow to B. Sigurbjörnsson, 18 Jul 1967, IAEA Archives, O/251 PT II.

38. For a detailed discussion of Silow's dissent, and the competing aims of FAO and IAEA, Hamblin, n. 19.
} 
in animal proteins rather than plants. In 1967 Swaminathan claimed that these levels were nearly comparable to the lysine found in milk protein. Because such protein was crucial for child brain development, he wrote, Sharbati Sonora wheat offered a cheap and practical way of «diminishing the threat of intellectual dwarfism ${ }^{39}$. At last, the IAEA seemed to have a truly impressive success story in an ideal region of the world: radiation had paved the way to addressing protein deficiency in India, a country under immense population pressure.

Skeptics argued that this approach - trying to improve protein contentcame at a high cost. As one researcher, R. O. Whyte, put it,

«I am concerned that the present stress on the protein content of cereals as the answer to Asia's problems is not giving due account to the equally important role of vitamins, minerals and fats, nor to the question of the relative merits of plant and animal protein in the Asian diet» ${ }^{40}$.

Whyte pointed out that India's stress on raising lysine content might disrupt the balance of other essential amino acids in the grain. It seemed as if the IAEA simply wanted scientists to get a mutant with increased protein content, ignoring all the other factors.

Scientists at the IAEA had quick answers to this and all other objections. Vitamins, minerals, and fats could be added as dietary supplements. And rather than assess the relative merits of animal and plant protein in Asians' diets, FAO/IAEA joint division official Robert A. Luse noted, the simplest course was to improve protein in existing dietary staples. If people were willing to buy wheat, then it made sense to alter it to suit dietary needs rather than try to convince people to buy something different ${ }^{41}$. This was precisely what Swaminathan was supposedly adept at doing -altering something that already was accepted by consumers.

By that time, Björn Sigurbjörnsson had become deputy director of the entire FAO/IAEA joint division, so his purview included other fields than mutation plant breeding. Others filled his shoes, notably Luse, a Berkeleytrained agricultural chemist under whom the IAEA became a stalwart

\footnotetext{
39. Hanlon, n. 2.

40. R. O. Whyte to Robert A. Luse (Plant Breeding and Genetics Section, Joint FAO/IAEA Division), 3 oct 1968, IAEA Archives, SC/822 (5) PT V.

41. Robert A. Luse to R. O. Whyte (Hongkong and Shanghai Banking Corporation, Ltd.), 24 Oct 1968, IAEA Archives, SC/822 (5) PT V.
} 
defender of Swaminathan's approach to plant improvement by increasing protein content. Luse argued that there were millions of people on the edge of starvation who had little access - or little money - to pay for animal protein. Research on increasing protein - whether by finding mutations, hybridizing existing ones, or inducing new ones with radiation- seemed to be the path toward helping the poorest people of the world ${ }^{42}$.

Finding out that scientists could use atomic energy to compel nature to provide more protein amidst a population crisis would have been important. The studies turned heads not only in the developing world, but also in leading research centers where mutation breeding was no longer taken seriously. In 1969 the IAEA received an almost apologetic letter from Robert Rabson of the US Atomic Energy Commission, which had downplayed mutation plant breeding over the previous decade. He said that he had been surprised that now their American contractors were interested in finding ways to stimulate yield with radiation. «So you see we are getting drawn into the question just a little further with time» ${ }^{43}$.

Upon closer inspection, the protein results could not be verified. Swaminathan gradually backed off his claim, and eventually the IAEA did too. Within the agency, at least one employee (Silow) tried to hold Sigurbjörnsson and his colleagues accountable for prematurely announcing the finding. But the agency rallied against him and he was successfully marginalized. In the end, what began as a strong claim about directing nature to solve the protein crisis was soon downgraded to a convenient change of color that suited the market better. The professional casualties were those who tried to speak up - Silow, the marginalized employee, and Shah, who ultimately committed suicide ${ }^{44}$.

The political stakes had been high. Joseph Hanlon later argued in The New Scientist, «On an international level, the most dramatic effect of Sharbati Sonora was to save the flagging FAO/IAEA atomic energy programme». But that was just one of the political stakeholders, among whom were Swaminathan and other mutation breeders all over the world, politicians wanting to claim top notch peaceful atomic energy programs in their own

42. Luse, Robert A. Plant protein improvement: a partial solution to the problem of protein malnutrition. Kalamazoo College Review. 1973; 35 (3): 3-6.

43. Robert Rabson (Assistant Chief, Biology Branch, Division of Biology and Medicine, AEC) to Maurice Fried (Director, FAO/IAEA Joint Division), 25 Apr 1969, IAEA Archives, SC/822 (4).

44. Hamblin, n. 19. 
countries, and of course an American foreign policy that had promoted peaceful atoms for nearly two decades. Shah addressed his suicide note to Swaminathan, complaining of many inequities in the laboratory. «I think the time has come again that a scientist will have to sacrifice his life in disgust so that other scientists may get proper treatment», he wrote. Perhaps more inflammatory was his claim that «a lot of unscientific data are collected and passed on to you to fit your line of thinking». The tragic event sparked an outcry in the scientific community and beyond, provoking the Indian government to conduct an inquiry into the activities of the Indian Council for Agricultural Research, of which Swaminathan now was director ${ }^{45}$.

Assessing the previous decade's work, Sigurbjörnsson wrote in 1971 that the attitude among plants breeders toward radiation-induced mutations ranged between over-enthusiasm to skepticism. Trying to seem objective, he wrote «Our Joint Division of the FAO and IAEA has attempted to steer a middle course between these views» ${ }^{46}$. This was not the case at all. The IAEA was a global lifeline for a scientific program in jeopardy.

\section{Conclusion}

Combining the population-explosion rhetoric of environmentalists and the humanitarian ethos of FAO, the IAEA scientists turned a tiny, marginalized research field into a critical component in the narrative of the Green Revolution. They had found shade under a big tent. In his Nobel Peace Prize lecture in 1970, plant breeder Norman Borlaug implored governments and scientists to invest heavily in agricultural research to address the population crisis, including mutation plant breeding, rather than in nuclear arms for the destruction of humanity ${ }^{47}$. IAEA scientists tried to ride the wave of this clarion call from the principal celebrity of the Green Revolution as best they could, pointing to Sharbati Sonora, the durum wheat trials in the Mediterranean region, and a high-yielding Japanese rice called Reimei ${ }^{48}$. Because numerous

\footnotetext{
45. Hanlon, n. 2.

46. Sigurbjörnsson, n. 27.

47. Borlaug, Norman. The green revolution, peace, and humanity. Nobel Lecture, 11 Dec 1970. Available from: http://nobelprize.org/nobel_prizes/peace/laureates/1970/borlaug-lecture.html.

48. Maurice Fried (Director, FAO/IAEA Joint Division) to E. J. Wellhausen (Director-General, International Maize and Wheat Improvement Center), 23 Dec 1968, IAEA Archives, SC/822 (4).
} 
crop varieties around the world had been altered by radiation treatment, the IAEA attempted to insert these as successes within the narrative of the Green Revolution. Most of these accomplished the same feat as the Italian durum wheats -increasing the stiffness of a stem, or making it shorter, so that vast increases in fertilizer inputs could be maintained without making plants fall under their own weight. Other traits included early maturity or disease resistance. These were rarely improvements in nutritional quality. Most of the success stories were subjective, as in the aesthetics of ornamental flowers. And most of those were from X-Ray treatments, not from gamma sources requiring radioactive materials. The IAEA claimed radiation was responsible for saving peppermint from extinction - because American researchers had used it to produce disease-resistant varieties ${ }^{49}$.

Åke Gustafsson, then the grand old man of mutation breeding, went so far as to say that the Green Revolution was just the first step in Green Evolution. After all, mutations were the source of genetic variability. Most of that variability occurred naturally, spontaneously due to several causes such as radiation from space, over long stretches of time. But with modern technology - and particularly with induced radiation - that process could be directed and sped up. Björn Sigurbjörnsson wrote in 1971 that the work of the IAEA was «quickening the pulse of nature». Radiation promised to speed up the rate of spontaneous mutation to give researchers a larger number to work with ${ }^{50}$.

Swaminathan went on to great fame and influence. He would become director of the IRRI - the very organization that first had dismissed the importance of radiation-induced mutation breeding. For decades, he sustained a reputation as a major figure in the Green Revolution. He received the General Foods World Food Prize in 1987 -along with its hefty reward, $\$ 200,000$. He later went into politics in India and, in a 2009 retrospective interview in Science, was dubbed a "guru of the Green Revolution» ${ }^{51}$.

In the 1980s, when he had become the director of the FAO/IAEA joint division, Sigurbjörnsson again adapted to the times, saying that the Green Revolution had laid to rest the population doomsaying of the 1970s. Despite what Malthus had predicted, food production had outpaced population

\footnotetext{
49. Radiation and the green revolution. IAEA Bulletin. 1969; 11 (5): 16-27.

50. Sigurbjörnsson, n. 27.

51. Havener, Robert D. Scientists: their rewards and humanity. Science. 1987; 237 (4820): 1281; A guru of the green revolution reflects on Borlaug's legacy. Science. 2009; 326 (5951): 361.
} 
growth. «From the very beginning of this green revolution», he wrote, «nuclear techniques played a significant role». By this he meant not only mutation breeding, but also using radioactive tracers for fertilizer studies, and for programs in food preservation and insect control. But for Sigurbjörnsson and the other experts who carved out a world of support at the IAEA, the important thing was to impress upon the world the importance of mutation breeding in the Green Revolution:

«At the present time, nearly 1,000 crop varieties derived from radiationinduced mutations are grown worldwide on several million hectares. If all varieties with mutants in their parentage are counted, the number reaches possibly tens of millions. The annual economic gains are measured in billions of dollars» ${ }^{52}$.

If the IAEA were to be believed, mutation plant breeding was one of the world's greatest blessings, having ameliorated an environmental crisis and elevated the lives of millions. That it could make such claims is not a mark of genuine impact. Instead, it is a testament to the IAEA's deliberate attempts, through the efforts of a cadre of officials beginning in the 1960s, to elevate the status of mutation plant breeding, first supporting a small transnational community of researchers in industrialized countries, and then trying to bolster the field's legitimacy by claiming victories for atomic energy in aiding the developing world. It pursued these aims against the advice of its advisors, against internal dissent, and in the face of its own failures, painstakingly protecting the idea of agricultural improvement through atomic energy.

52. Sigurbjörnsson, Björn, Leo E. La Chance. The IAEA and the green revolution: from research laboratories to farmers' fields, nuclear techniques are making a difference. IAEA Bulletin. 1987; 29 (3): 38-42 (39) 